\title{
Bal Arısı ve Bal Arısı Ürünleri
}

\section{Mukaddes ARIGÜL APAN1(D), Murat ZORBA ${ }^{2}$ ve Ümit KAYABOYNU1(iD}

How to cite: Arıül Apan, M., Zorba, M., \& Kayaboynu, Ü. (2021). Bal arıs1 ve bal arıs1 ürünleri. Sinop Üniversitesi Fen Bilimleri Dergisi, 6(2), 202-223. https://doi.org/10.33484/sinopfbd.992345

\section{Derleme}

\section{Sorumlu Yazar}

Murat ZORBA

murat_zorba@comu.edu.tr

\section{Yazarlara ait ORCID}

M.A.A: 0000-0002-1469-9815

M.Z: 0000-0003-3763-3453

Ü.K: 0000-0002-0418-8325

Received: 08.09 .2021

Accepted: 09.12.2021

\section{$\ddot{O} z$}

Türkiye farklı iklim ve coğrafi şartlara sahip olduğu için çok çeşitli bal arı ırklarının merkezi konumundadır. Türkiye'de yaygın olarak Anadolu arısı (Apis mellifera anatolica M.), Kafkasya arıs1 (Apis mellifera caucasia G.), Suriye Arıs1 (Apis mellifera syrica), İran arısı (Apis mellifera meda Skorikov, 1929) ırkları bulunmaktadır. Arıcılığın geçmişi Taş Devri ve eski medeniyet çağlarına kadar dayanmaktadır. İspanya'da yapılan kazılarda ortaya çıkarılan M.Ö. 7000 yıllarına ait arı fosil ve resimleri eski çă̆ insanlarının doğal yaşamlarında arılardan yararlandığını kanıtlamaktadır. Arının kültüre alındığı ilk yer Mısır olup, arıcılığın ise ilk defa 7000 yıl önce Orta Anadolu'da başladığı bilinmektedir. Literatürde Mısırlılarda arıcılığın daha da geliştiği, 4.000 yıl öncesinde balın malların alım satımında takas malzemesi olduğu ve vergi ödemede kullanıldığ belirtilmektedir. Günümüzde arıcılık sektörü oldukça gelişmiş ve bal dışında diğer arı ürünlerinin önemi de araştırmacılar tarafından keşfedilmiştir. Bal dışındaki diğer arı ürünleri arasında propolis, arı sütü, polen, arı ekmeği (Perga), arı zehiri ve balmumu yer almaktadır. $\mathrm{Bu}$ çalışmada arı ürünlerinin tanıtılması, beslenme ve sağlık açısından önemlerinin vurgulanması amaçlanmaktadır.

Anahtar Kelimeler: Propolis, bal, arı sütü, polen, arı ekmeği

\section{Honey Bee and Honey Bee Products}

\section{${ }^{1}$ T.C. Tarım ve Orman Bakanlığı, Arıcılık Araştırma Enstitüsü, Ordu, Türkiye}

\begin{abstract}
${ }^{2}$ Çanakkale Onsekiz Mart Üniversitesi, Mühendislik Fakültesi, Gıda Mühendisliği Bölümü, Çanakkale, Türkiye
\end{abstract}

Bu çalışma Creative Commons Attribution 4.0 International License ile lisanslanmıştır

\section{Abstract}

Turkey is the regional center for various honey bee races because of different climatic and geographical conditions. Anatolian race (Apis mellifera anatolica M.), Caucasian race (Apis mellifera caucasia G.), Syrian race (Apis mellifera syrica), Iranian race (Apis mellifera meda Skorikov, 1929) are common races found in Turkey. The history of the apiculture dates back to the Stone Age and the ancient civilizations. The bee paintings and fossils found in excavations in Spain show that people have been benefiting from the bees in their natural life since the $7000 \mathrm{BC}$. It is known that the first place for bee cultivation is Egypt and the beekeeping has been firstly started for 7000 years ago in Central Anatolia. It is also stated through the literatures that the apiculture was more developed by Egyptians and that honey was used as an interchanging material in the purchasing of goods and in tax payments 4000 years ago. Today, many developments are being done in the beekeeping industry. The researchers pay attention the importance of other bee products besides 
Keywords: Propolis, honey, royal jelly, pollen, bee bread

\section{Giriş}

Eski çağlarda insanlar tarafından kaya ve ağaç kovuklarında bulunan oğul arıların öldürülmesiyle geride kalan balların tüketildiği bilinmektedir. Arıcılığın, balın arıların kışlık deposu olduğunun anlaşılması sonucu, kaya ve ağaç kovuklarında yuvalanan arıların öldürülmeden balın bir kısmının alınırken bir kısmının da arıların tüketimi için ayrılmasıyla başladığı düşünülmektedir [1]. Arılardan bal almak amacıyla yetiştirilmeye başlandığı zamanlarda bal arılarının doğada bulundukları yerleri andıran saz, kütük gibi materyallerden imal edilen kovanlar kullanılmıştır. Bal arılarının yaşam döngüsünün araştırılması ile orta çağda arıcılık gelişmeye başlamıştır [2]. Günümüze değin geliştirilerek modernleştirilen arıcılık teknikleri ile dünya piyasasında özellikle bal olmak üzere arı ürünleri oldukça önemli bir yer bulmuştur. Propolis, bal, arı sütü, polen, arı ekmeği (perga), arı zehiri ve balmumu birer arı ürünüdür. Arı ürünleri içerisinde pek çok kişi tarafından en çok bilinen ürün baldır. Ancak diğer arı ürünleri de bal kadar şifalıdır ve her birinin değeri gelişen analiz teknikleri ile gün geçtikçe daha çok araştırılarak belirlenmektedir. Bu derleme çalışmasında; arı ürünlerinin tanıtılması, beslenme ve sağlık açısından önemlerinin açıklanarak vurgulanması amaçlanmaktadır.

\section{Bal Arısının Dünya'ya Yayılması}

Bal arılarının gen merkezi Afrika, Asya ve Avrupa kıtaları olduğu bildirilmektedir. Yeni dünya ülkelerine göç eden insanlar arı kolonilerini de taşımışlar ve böylece bütün dünyaya bal arılarının yayılması sağlanmıştır. Bal arıları; 1683'te Kuzey Amerika'ya, 1822'de Avustralya'ya ve 1842'de Yeni Zelanda'ya götürülmüştür. Bal arılarının Amerika'nın batı tarafına girişi 1850 yılında gerçekleşmiştir. Böylece Apis mellifera türüne bağlı bal arılarının 5 kıtada yaklaşık 200-250 yıldan beri yaşamı süregelmektedir [3]. Arıcıllğın önemli hale gelmesinin nedenleri:

a) Az sermaye ile her kesim tarafından yapılabilecek bir üretim dalı olması ve buna karşıllık yüksek gelir elde edilebilmesi,

b) İşletmede en çok tavukçuluk sektörü ile bağdaşması nedeniyle düşük iş gücü girdileri ile iki sektörün birleştirilebilmesi,

c) Arı ürünlerinin beğenilerek tüketilmesi nedeni ile sürekli pazar imkanının olması,

d) Bitkilerin tozlaşmasında bal arılarının önemli rol oynaması ve ayrıca bal arılarının bitkilerin tozlaşması gereken tarım alanlarına rahatıkla taşınabilmesidir. 
Günümüzde dünyada gıdaların \%90'lık bölümü 82 bitki türünden üretilmektedir. Bu bitki türlerinden 63'ünün (\%77'si) arılar tarafından tozlaşması gerekmekte olup, 39'unda da mutlaka arının polinasyon faaliyeti gerekmektedir. İnsanların ihtiyaç duyduğu gıda maddelerinin üçte biri, arının polinasyon faaliyetine ihtiyaç duyan bitkilerden oluşmaktadır [3].

\section{Bal Arısının Taksonomik Gruplandırmadaki Yeri}

Bal arısı alt türleri bulundukları bölgeye doğal seleksiyon yoluyla uyum sağlamışlardır. Bugün tanımlanan Apis mellifera 1rk sayısı (alt türü) 27 adettir. Söz konusu ırkların oluşumuna etki eden faktörler arasında; coğrafik değişiklikler, bu bölgelerde meydana gelen izolasyonlar ve bu nedenle oluşan iklimsel farklılıklar yer almaktadır [5]. Bal arılarının taksonomik gruplandırmadaki yeri Tablo 1 ' de verilmektedir.

Tablo 1. Bal arılarınin taksonomik sinıflandırılması [3]

\begin{tabular}{lll}
\hline Alem & Animalia & Hayvanlar \\
\hline Şube & Arthropoda & Eklem bacaklılar \\
Sinıf & Insecta & Böcekler \\
Alt Sınıf & Pterygota & Kanatlı böcekler \\
Takım & Hymenoptera & Zar Kanatlilar \\
Bölüm & Aculeata & Ĭgneliler \\
Süper Familya & Apoidea & Arılar \\
Familya & Apidae & \\
Alt Familya & Apinae & \\
Cins & Apis & Bal arıları \\
Tür & Apis mellifera Linnnaeus, 1758 & Batı bal arıs1 \\
& Apis cerena Fabricius, 1793 & Doğu bal arıs1 \\
& Apis florea Fabricius, 1787 & Cüce arı \\
& Apis dorsata Fabricius, 1793 & Dev arı \\
\hline
\end{tabular}

Türkiye'nin batısında, kuzeydoğusunda, güneydoğusunda ve Orta Anadolu'da 4 bal arıs1 alt türü bulunduğu belirtilmiştir. Ruttner [4] tarafından yapılan çalışmada; Türkiye-Suriye sınırı boyunca ve Hatay ili çevresinde A. m. syriaca, Güneydoğu Anadolu bölgesinde A. m. meda, Samsun'dan Türkiye'nin kuzey doğusuna kadar olan alanda A. m. caucasica, Türkiye'nin diğer bölgelerinde ise $A$. m. anatoliaca bulunduğu belirtilmektedir. Ülkemizde TUİK tarafindan düzenlenen verilere göre; 2020 yılında arıcılık yapan işletme sayısı 82.845 iken, arı ürünlerinin en başından gelen bal üretim miktarı 104.077 ton ve balmumu ise 3.765 tondur [6]. Günümüzde bal ve balmumunun yanı sıra; propolis, arı sütü, polen, arı ekmeği, arı zehiri, apilarnil önemlerinin bilindiği arı ürünleri arasında yer almaktadır.

\section{Bal}

Türk Gıda Kodeksi Bal Tebliği’ne göre bal; ‘Bitki nektarlarının, bitkilerin canlı kısımlarının salgılarının veya bitkilerin canlı kısımları üzerinde yaşayan bitki emici böceklerin salgılarının bal arısı tarafından toplandıktan sonra kendine özgü maddelerle birleştirerek değişikliğe uğrattığı, su içeriğini düşürdüğü ve petekte depolayarak olgunlaştırdığı doğal ürünü' olarak ifade edilmektedir [7]. Arıların kovan 
içerisinde topladıkları nektar ve salgıları metabolize ederek bala dönüştürmesi biyokimyasal bir olaydır. Arının topladığı nektar kaynağına göre bal; çiçek balı ve salgı balı olarak iki çeşittir. Çiçek balının kaynağı çiçeklerin nektarı (geven, lavanta, ayçiçeği, akasya, üçgül balı vb.) iken; çam, köknar ve meşe balı gibi salgı balının orijinini ise bitki veya bitki üzerindeki böcek salgıları oluşturmaktadır $[8,9]$. Bal Tebliği'ne göre balın taşıması gereken genel özellikleri Tablo 2'de gösterilmektedir.

Tablo 2. Balın taşıması gereken genel özellikleri [7]

\begin{tabular}{|c|c|c|c|c|}
\hline Özellik & Çiçek Balı & Salgı Balı & $\begin{array}{l}\text { Çiçek ve Salgı } \\
\text { Balı Karışımı }\end{array}$ & $\begin{array}{l}\text { Firıncılık } \\
\text { balı }\end{array}$ \\
\hline & $\% 20$ & $\% 20$ & $\% 20$ & $\% 23$ \\
\hline Nem (en fazla) & $\begin{array}{l}\% 23 \\
\text { [Püren (Calluna } \\
\text { vulgaris ve Funda } \\
\text { (Erica } \mathrm{spp}) \\
\text { ballarında] }\end{array}$ & & & $\begin{array}{l}\% 25 \\
\text { [Püren ve } \\
\text { Funda } \\
\text { kaynaklı } \\
\text { firıncilık } \\
\text { ballarında] }\end{array}$ \\
\hline Sakkaroz (en fazla) & $\begin{array}{l}5 \mathrm{~g} / 100 \mathrm{~g} \\
10 \mathrm{~g} / 100 \mathrm{~g} \\
\text { [Yalancı akasya } \\
\text { (Robina } \\
\text { pseudoacacia), Adi } \\
\text { yonca (Medicago } \\
\text { sativa), Menzies } \\
\text { Banksia (Banksia } \\
\text { meziesii), Tatll yonca } \\
\text { (Hedysarum), Kırmızı } \\
\text { okaliptüs (Eucalyptus } \\
\text { camadulensis), Meşin } \\
\text { ağac1 (Eucryhia } \\
\text { lucida, Eucyrphia } \\
\text { milliganii) ve } \\
\text { Narenciye ballarında] } \\
\text { 15 g/100g } \\
\text { [Lavanta çiçeği } \\
\text { (Lavandula } \text { spp.), } \\
\text { Hodan (Boraga } \\
\text { officinalis) ballarında] }\end{array}$ & $5 \mathrm{~g} / 100 \mathrm{~g}$ & $5 \mathrm{~g} / 100 \mathrm{~g}$ & $5 \mathrm{~g} / 100 \mathrm{~g}$ \\
\hline $\begin{array}{l}\text { Fruktoz + Glukoz (en } \\
\text { az) }\end{array}$ & $60 \mathrm{~g} / 100 \mathrm{~g}$ & $45 \mathrm{~g} / 100 \mathrm{~g}$ & $45 \mathrm{~g} / 100 \mathrm{~g}$ & - \\
\hline Fruktoz/Glukoz & $\begin{array}{l}0.9-1.4 \\
1.0-1.85 \\
{[\text { Kestane (Castenea }} \\
\text { sativa)] } \\
1.2-1.85 \\
\text { [Akasya (Robinia } \\
\text { pseudoacacia)] } \\
1.0-1.65 \\
\text { [Kekik (Thymus spp.)] }\end{array}$ & $1.0-1.4$ & $1.0-1.4$ & - \\
\hline Maltoz (\%, en fazla) & 4 & 4 & 4 & - \\
\hline
\end{tabular}


Tablo 2.'nin devamı...

\begin{tabular}{|c|c|c|c|c|}
\hline Özellik & Çiçek Balı & Salgı Balı & $\begin{array}{l}\text { Çiçek ve Salgı } \\
\text { Balı Karışımı }\end{array}$ & $\begin{array}{l}\text { Firıncilık } \\
\text { balı }\end{array}$ \\
\hline $\begin{array}{l}\text { Suda çözünmeyen } \\
\text { madde (en fazla) }\end{array}$ & $0.1 \mathrm{~g} / 100 \mathrm{~g}$ & $0.1 \mathrm{~g} / 100 \mathrm{~g}$ & $0.1 \mathrm{~g} / 100 \mathrm{~g}$ & $0.1 \mathrm{~g} / 100 \mathrm{~g}$ \\
\hline Serbest asitlik (en fazla) & $50 \mathrm{meq} / \mathrm{kg}$ & $50 \mathrm{meq} / \mathrm{kg}$ & $50 \mathrm{meq} / \mathrm{kg}$ & $80 \mathrm{meq} / \mathrm{kg}$ \\
\hline Elektrik iletkenliği & $\begin{array}{l}\text { En fazla } 0.8 \mathrm{mS} / \mathrm{cm} \\
\text { [Kocayemiş (Arbutus } \\
\text { unedo), Funda (Erica } \\
\text { spp.), Okaliptüs } \\
\text { (Eucalyptus } \\
\text { camaldulensis), } \\
\text { Ihlamur (Tilia spp.), } \\
\text { Püren (Calluna } \\
\text { vulgaris), Okyanus } \\
\text { mersini } \\
\text { (Leptospermum), Çay } \\
\text { ağac1 (Melaleuca } \\
\text { spp), ve Pamuk } \\
\text { (Gossypium spp.)'dan } \\
\text { elde edilen ballar } \\
\text { hariç] } \\
\text { En az } 0.8 \text { mS/cm } \\
\text { [Kestane balında] }\end{array}$ & $\begin{array}{l}\text { En az } 0.8 \\
\mathrm{mS} / \mathrm{cm}\end{array}$ & $\begin{array}{l}\text { En az } 0.8 \\
\mathrm{mS} / \mathrm{cm} \\
\text { [Kestane balı ve } \\
\text { salgı balı } \\
\text { karışımlarında] }\end{array}$ & $\begin{array}{l}\text { En fazla } 0.8 \\
\mathrm{mS} / \mathrm{cm}\end{array}$ \\
\hline Diastaz sayıs1 (en az) & $\begin{array}{l}8 \\
3 \\
\text { [Narenciye balı gibi } \\
\text { yapısında doğal } \\
\text { olarak düşük miktarda } \\
\text { enzim bulunan ve } \\
\text { doğal olarak HMF } \\
\text { miktarı } 15 \text { mg/kg'dan } \\
\text { fazla olmayan balda] }\end{array}$ & 8 & 8 & - \\
\hline HMF (en fazla) ${ }^{* *}$ & $40 \mathrm{mg} / \mathrm{kg}$ & $40 \mathrm{mg} / \mathrm{kg}$ & $40 \mathrm{mg} / \mathrm{kg}$ & - \\
\hline Bal $\delta^{13} \mathrm{C}$ değeri $\left(\delta^{13} C_{b a l}\right)$ & -23 ve daha negatif & $\begin{array}{l}\text {-23 ve daha } \\
\text { negatif } \\
\text { [Çam } \\
\text { balinda - } \\
22.5 \text { ve } \\
\text { daha } \\
\text { negatif] }\end{array}$ & $\begin{array}{l}-23 \text { ve daha } \\
\text { negatif }\end{array}$ & - \\
\hline $\begin{array}{l}\text { Balda protein }\left(\delta^{13} \mathrm{C}_{\text {protein }}\right) \\
\text { ve bal }\left(\delta^{13} \mathrm{C}_{\text {bal }}\right) \delta^{13} \mathrm{C} \\
\text { değerleri arasındaki fark }\end{array}$ & -1.0 veya daha pozitif & $\begin{array}{l}\text {-1.0 veya } \\
\text { daha pozitif } \\
\text { [Çam } \\
\text { balında bu } \\
\text { kriter } \\
\text { aranmaz] }\end{array}$ & $\begin{array}{l}-1.0 \text { veya daha } \\
\text { pozitif }\end{array}$ & $\begin{array}{l}-1.0 \text { veya } \\
\text { daha pozitif }\end{array}$ \\
\hline
\end{tabular}


Tablo 2.'nin devamı...

\begin{tabular}{|c|c|c|c|c|}
\hline Özellik & Çiçek Balı & Salgı Balı & $\begin{array}{l}\text { Çiçek ve Salgı } \\
\text { Balı Karışımı }\end{array}$ & $\begin{array}{l}\text { Firıncilık } \\
\text { balı }\end{array}$ \\
\hline $\begin{array}{l}\text { Balda protein ve bal } \\
\delta^{13} \mathrm{C} \text { değerlerinden } \\
\text { hesaplanan } \mathrm{C} 4 \text { şekerleri } \\
\text { oran1 (en fazla) }\end{array}$ & $\% 7$ & $\begin{array}{l}\% 7 \\
\text { [Çam } \\
\text { balında bu } \\
\text { kriter } \\
\text { aranmaz] } \\
\end{array}$ & $\% 7$ & $\% 7$ \\
\hline Prolin miktarı (en az) & $\begin{array}{l}300 \mathrm{mg} / \mathrm{kg} \\
180 \mathrm{mg} / \mathrm{kg} \\
\text { [Kanola, ihlamur, } \\
\text { narenciye, lavanta, } \\
\text { okaliptüs ballarında] } \\
120 \mathrm{mg} / \mathrm{kg} \\
\text { [Biberiye, akasya } \\
\text { ballarında] } \\
500 \mathrm{mg} / \mathrm{kg} \\
\text { [Kestane ballarında] }\end{array}$ & $300 \mathrm{mg} / \mathrm{kg}$ & $300 \mathrm{mg} / \mathrm{kg}$ & $180 \mathrm{mg} / \mathrm{kg}$ \\
\hline $\begin{array}{l}\text { Naftalin miktarı } \\
\text { (en fazla) })^{* * *}\end{array}$ & $10 \mathrm{ppb}$ & $10 \mathrm{ppb}$ & $10 \mathrm{ppb}$ & $10 \mathrm{ppb}$ \\
\hline
\end{tabular}

Balın yapısında yaklaşık 200 farklı bileşen bulunmakta ve balın kimyasal özelliklerini etkileyen iki temel faktör olarak coğrafi ve botanik kaynak gösterilmektedir. Bileşiminde bulunan aminoasitler ve enzimler, organik asitler, flavonoidler, fenolik asitler mineraller, vitaminler gibi besin öğeleri ile gerek besleyici gerekse çoğu hastalığa karşı tedavi edici ve koruyucu nitelikte fonksiyonel bir gida olarak gösterilmektedir [10,11]. En eski tıp literatürü olarak kabul edilen bir tablette Sümerli hekimler tarafından yazılmış 5000 yıl öncesine ait bir bal reçetesi bulunmaktadır. Yapılan araştırmalarda; 2000 y1l kadar önce henüz bakterilerin enfeksiyon nedeni olarak bilinmediği dönemde, balın enfekte olmuş yaralarda kullanıldığı bildirilmektedir. Mısırlılar tarafından söz konusu özelliği keşfedilen bu arı ürünü; cerrahi pansumanlar, göz iltihaplarının tedavisi gibi uygulamalar ile tıp alanında yer almıştır [12-14]. Çin ve Hindistan' da çiçek hastalığının yayılmasını engellemek amacıyla hasta bireylerin vücutları bal ile kaplanmıştır. Geçmiş yıllarda balın; İngiliz, Alman ve Amerikan hastanelerinde birinci sınıf mikrop öldürücü niteliğinde görüldüğü bilgisi literatürde yer almıştır. Fransız bilim insanları tarafından balın tedavi edici etkisinin araştırıldığı bir çalışmada, bal bileşiminde bulunun hidrojen peroksitin küf, maya gelişimini önleyici etkisi rapor edilmiştir $[15,16]$. Hidrojen peroksitin yanı sıra; balın antimikrobiyal özellikleri üzerine farklı etmenler de etki etmektedir. Bu etmenler; balın bileşiminden kaynaklanan yüksek osmoz basıncı, düşük su aktivitesi, asitlik, katalaz enzimi, polifenoller, fenolik asitler (kafeik asit, ferulik asit) ve türevleri, aromatik asitler, flavonoidler, organik asitler (glukonik asit gibi, lizozim ve uçucu bileşikler gibi peroksit olmayan bileşikler olarak belirtilmektedir [12, 17-22]. Ayrıca yapılan bir araştırmada; koyu renkli balların açık renkli ballara kıyasla yüksek fenolik bileşen içeriği nedeniyle antimikrobiyal aktivitesinin de daha yüksek olduğu belirlenmiştir $[19,22]$. Balın bağırsak ve mide 
üzerine iyileştirici etkileri olduğu, hazımsızlık ve peptik ülser hastalıklarına karşı kullanıldığı bilinmektedir [23-27] Yapılan araştırmalarda karaciğer rahatsızlıklarında, diyabette ve diş plağı oluşumunu azaltmada balın etkili olduğu belirtilmektedir [28-31]. Bal bileşiminde bulunan fenolik bileşikler ve flavonoidlerin kanser etmeni olan oksidatif stresi ve serbest radikal oluşumunu engellediği, antikansorejen, antitümör, antilösemik etki göstermesinin yanı sıra kemoterapi ilaçlarının antitümör aktivitesini arttırdığı da yapılan çalışmalarda belirtilmektedir [32-37].

\section{Polen}

Bal arıları gereksinimlerini karşılamak için bitkiden polen ve nektar toplaması yoluyla söz konusu bitkinin polinasyonunu (tozlaşmayı) sağlamaktadırlar. Bal arılarının bitkilerin çiçeklerinden nektar almaları sırasında; vücutlarındaki kıllara yapışan polen tozları orta bacaklarda bulunan firça ile toplanmakta ve ağzındaki bal ile nemlendirilerek arka bacaklarında bulunan polen sepetçiğinde biriktirilmektedirler. Arka bacağında topladığı polenleri, bu bacakta yer alan firça ve tarak olarak adlandırılan özel yapıları ve bacaklarının birbirine sürtülmesi yoluyla polen sepetine yerleștiren arılar söz konusu işlemi uçma sırasında bile sürdürürler. Arılar uçuşa çıktığında kovana yalnızca polen yükü ile geri gelebildiği gibi hem polen hem nektar yükü ile birlikte de gelebilirler. Arılar kovana geri döndüğünde ise; polen peletleri petek gözleri içine bırakmaktadırlar. Polen, sepetine (korbikula) doldurulmasının ardından polenin bozulmaması amacıyla arılar tarafından yüzeyi ince bir bal ve balmumu tabakası ile kaplanır. Polen, arıların büyüyüp gelişmelerini tamamlayabilmeleri için gerekli bir besin olup salgı bezlerinin gelişmesinde başrol oynayan protein kaynağıdır [38-41]. Polen, kovanın giriş deliği önünde konulan tuzaklar yoluyla elde edilebilmektedir. Tuzağın alt tarafinda toplanan polenlerin, nem ve sıcaklığın bozulmaya neden olmaması için toplama sonunda hemen alınması gerekmektedir. Polen kurutma işlemi, kurutma dolabında veya havalandırma sistemine sahip bir elektrikli fırında $30-35^{\circ} \mathrm{C} / 5-6$ saat parametrelerinde gerçekleştirilmektedir. Kurutma işlemine uygulanan polenler $1-2^{\circ} \mathrm{C}^{\prime}$ de hermetik cam ambalajlarda muhafaza edilebilmektedirler [40, 41]. Polen taneleri, yaklaşık olarak 6-200 $\mu \mathrm{m}$ boyutunda sıkıştırılmış polen tozlarından oluşmaktadırlar. Polen bileşiminde bulunan protein ve karbonhidratın yanı sıra vitamin ve mineral maddece zengin olması nedeniyle insan metabolizması için oldukça değerli bir besin maddesi olarak görülmektedir [38-41]. Polenin genel kimyasal bileşimi Tablo 3'te gösterilmektedir.

Arıların polene katkısı sabit olmakla birlikte; polenin bileşiminde bulunan maddeler nektar kaynağı olan bitki türüne ve çeşitliliğine bağlıdır. Farklı türlere ait polenlerin farklı şekil ve yapılarda olması bitkilerde tür tanımlamasında ve balın kaynağının belirlenmesinde kullanılmaktadır [46, 47]. Polen; vücut sağlığının korunması ve direncinin artırılmasının yanı sıra sağlıklı beslenme amacıyla, zihinsel ve bedensel yorgunluğun giderilmesinde, organ ve sistemlerin uyumlu ve verimli çalışmasında, çocukların büyümesinde, hormonal dengenin sağlanmasında, üreme problemlerinin çözümünde, düşünsel gücünün 
artırılmasında, sporcuların performanslarının artırılmasında, kansızlık tedavisinde ve karaciğer, kanser hastalıkları tedavisinde kullanılmaktadır [48, 49].

Tablo 3. Polenin genel kimyasal bileşimi [42-45]

\begin{tabular}{cccc}
\hline Bileşen & $\begin{array}{c}\text { Bileşen miktarı } \\
\text { (En az-En çok) }\end{array}$ & Bileşen & $\begin{array}{c}\text { Bileşen miktarı } \\
\text { (En az-En çok) }\end{array}$ \\
\hline Protein & $10-40 \mathrm{~g} / 100 \mathrm{~g}$ & Bakır & $2-16 \mathrm{mg} / 1000 \mathrm{~g}$ \\
Yăg & $1-13 \mathrm{~g} / 100 \mathrm{~g}$ & Manganez & $20-110 \mathrm{mg} / 1000 \mathrm{~g}$ \\
Karbonhidrat & $13-55 \mathrm{~g} / 100 \mathrm{~g}$ & Vitamin A & $10-200 \mathrm{mg} / 1000 \mathrm{~g}$ \\
Pektin & $0.3-20 \mathrm{~g} / 100 \mathrm{~g}$ & Tiyamin & $6-13 \mathrm{mg} / 1000 \mathrm{~g}$ \\
Kül & $2-6 \mathrm{~g} / 100 \mathrm{~g}$ & Riboflavin & $6-20 \mathrm{mg} / 1000 \mathrm{~g}$ \\
Potasyum & $4000-20000 \mathrm{mg} / 1000 \mathrm{~g}$ & Niasin & $40-110 \mathrm{mg} / 1000 \mathrm{~g}$ \\
Magnezyum & $200-3000 \mathrm{mg} / 1000 \mathrm{~g}$ & Pantotenik asit & $5-20 \mathrm{mg} / 1000 \mathrm{~g}$ \\
Kalsiyum & $200-3000 \mathrm{mg} / 1000 \mathrm{~g}$ & Vitamin C & $70-560 \mathrm{mg} / 1000 \mathrm{~g}$ \\
Fosfor & $800-6000 \mathrm{mg} / 1000 \mathrm{~g}$ & Vitamin H & $0.5-0.7 \mathrm{mg} / 1000 \mathrm{~g}$ \\
Demir & $11-170 \mathrm{mg} / 1000 \mathrm{~g}$ & Folik asit & $3-10 \mathrm{mg} / 1000 \mathrm{~g}$ \\
Çinko & $30-250 \mathrm{mg} / 1000 \mathrm{~g}$ & Vitamin E & $40-320 \mathrm{mg} / 1000 \mathrm{~g}$ \\
\hline
\end{tabular}

\section{Arı Sütü}

Ar1 sütünün önemi araştırmacılar tarafından 1600'lü yıllarda tespit edilmiş olup; bu ürüne İngilizce karş1lı̆̆ 'mükemmel besin' anlamına gelen "Royal Jelly" denilmiştir. Bu ürün; arıların 6-15 günlük işçi arıların yutak üstü salgı bezlerinden salgıladıkları, ana arı ve larva beslemede kullandıkları bir üründür. Söz konusu arı ürünü; ilk üç günlük tüm larvaların, ana arı olacak larvanın tüm larval dönemlerinde ve ana arıların yaşamları süresince beslendikleri tek kaynak olarak gösterilmektedir [49, 50]. Arı sütü kısmen suda çözünen, sarımsı beyaz renge, karakteristik ekşi tada ve keskin fenolik kokuya sahip, akıcı ve hamur yapısında, yoğunluğu yaklaşık olarak $1,1 \mathrm{~g} / \mathrm{cm}^{3}$ değerinde olan homojen bir madde olarak belirtilmektedir [50]. Arı sütünün ortalama kimyasal bileşimi Tablo 4’te verilmektedir.

Tablo 4. Arı sütünün kimyasal bileşimi [52, 53].

\begin{tabular}{ccc}
\hline Bileşen & $\begin{array}{c}\text { Bileşen miktarı } \\
\text { (Taze) }\end{array}$ & $\begin{array}{c}\text { Bileşen miktarı } \\
\text { (Liyofilize) }\end{array}$ \\
\hline Nem & $\% 60-70$ & $<\% 5$ \\
Protein & $\% 9-18$ & $\% 27-41$ \\
Lipit & $\% 3-8$ & $\% 8-19$ \\
Fruktoz+Glukoz+Sukroz & $\% 7-18$ & - \\
10-hidroksi-2-dekanoik asit & $>\% 1.4$ & $>\% 3.5$ \\
Kül (Mineral Madde) & $\% 0.8-3$ & $\% 2-5$ \\
pH & $3.4-4.5$ & $3.4-4.5$ \\
Asitlik (ml 0.1N NaOH/g) & $3.0-6.0$ & - \\
\hline
\end{tabular}

Bu ürünün kimyasal yapısı elde edilen mevsim, iklim koşulları, koloninin güçlü olması, larvanın yaşı, üretim yöntemi gibi çeşitli faktörlere bağlı olarak değişiklikler göstermektedir [51, 54]. Tablo 4'de 
belirtilen bileşenlerin yanı sıra; özellikle B kompleks vitaminleri olmak üzere vitaminlerce zengin olan bu arı ürününün 1 gramında bulunan vitamin içeriği ise Tablo 5 'te verilmiştir.

Tablo 5. Bir gram arı sütünün vitamin içeriği [52, 55]

\begin{tabular}{cc}
\hline Vitamin & Miktar $(\mathrm{mg} / 100 \mathrm{~g})$ \\
\hline Vit. B1 Thiamin & $0.1-1.7$ \\
Vit. B2 Riboflavin & $0.5-2.5$ \\
Vit.B3 Niasin & $4.5-19$ \\
Vit. B6 Pyridoxin & $0.2-5.5$ \\
Vit. H Biotine & $0.15-0.55$ \\
Pantotenik Asit & $3.6-23$ \\
Folik Asit & $0.01-0.06$ \\
\hline
\end{tabular}

Yapılan çalışmalarda; B vitaminlerinin tamamı ayrıca, E, D ve C vitaminleri ve ile bazı vitaminlerin de arı sütü bileşiminde olduğu belirtilmektedir. Arı sütünde kalite faktörlerinde birisi de 10-hidroksi- $\alpha$-2dekanoik asit (10-HDA) bileşeninin miktarıdır. Arı Sütü Standardında; 10-HDA değeri saf arı sütünde $\% 1.4$ 'ten az, bala karıştırılmış arı sütünde \%0.16'dan az, liyofilize edilmiş arı sütünde ise $\% 3.5$ 'den az olmamalıdır [56]. Yapılan araştırmalarda; arı sütünün antibakteriyel ve antioksidan özelliklerinin bileşiminde bulunan 10-HDA maddesinden kaynaklandığı bildirilmiştir [57-59]. Arı sütünün; dayanıklılı̆gı arttıııı, ruhsal gerginlik hissini azaltıcı, rahatlatıcı, iştah arttırıcı, zindelik kazandırıcı özelliklerinin yanı sıra; birçok hastalığı önleyici ve tedavi edici özellikleri ile fonksiyonel bir gıda olduğu belirtilmektedir [60-62]. Arı sütünün bağışıklık sistemini düzenleyici etkiye sahip olduğunu belirleyen çalışmalar, söz konusu etkinin alerji, inflamasyon ve kanser üzerine olan etkilerinin araştırılmasına sebep olmuştur. Antiallerjik ve anti inflamatuar etkilere neden olabileceğini gösteren çalışmalar bulunmakla birlikte, insanlarda yaşlanmayı geciktirici özelliğinin anti-inflamatuar etki mekanizması ile sağlanabildiği fikri de ortaya atılmıştır. Aynı zamanda, nörotrofik, nöroprotektif etki gösterdiği ve beyin hücre diferansiyasyonunu doğrudan etkilediği, merkezi sinir sistemini uyarıcı etkisi olduğu sonuçlarına ulaşıldığı ifade edilmektedir. Ar1 sütünün bileşiminde bulunan proteinlerin antioksidatif özelliğe sahip olduğu ve bu sayede; yaşlanmayı geciktirici, karaciğeri koruyucu, radyasyonun olumsuz etkilerini azaltma üzerinde etkilerinin belirlenmesine yönelik çalışmalarda olumlu sonuç elde edildiği belirtilmektedir [54, 63].

\section{Propolis}

Bal arıları; bitkilerin meyve, çiçek ve yapraklarını antimikrobiyal bozulmayı önlemek amacıyla ürettikleri su geçirmeyen ve 1sı yalıtımını sağlayan reçinemsi maddeleri, ağaçların gövdelerinde bulunan yapraklardan, tomurcuklardan ve çatlaklardan toplarlar. Toplanan bu maddelerin çeşitli amaçlarda kullanılmak üzere arılar tarafından çiğnenmesi, ağız yoluyla sindirim enzimlerinin eklenmesi ve belirli oranda sindirilerek balmumuyla karıştırılması ile propolis adı verilen yapışkan madde elde edilmektedir. Bal arıları propolisi, larva gözlerine yumurta bırakılmadan önce cilalama, kovan iç yüzeyini kaplama, 
yarık ve çatlakların kapatma, petek kenarlarının sertleştirerek onarma, kovan girişlerinin kolaylıkla savunulacak hale dönüştürülmesi gibi amaçlarla kullanmaktadırlar [41, 61, 64, 65]. Propolis sarıdan koyu kahverengiye bazı durumlarda yeşile yakın renklerde olabilmektedir. Propolisin rengini ve kokusunu etkileyen en önemli üç faktör; toplandığı bölge, mevsim ve botanik köken olarak belirtilmektedir. Tat açısından değerlendirildiğinde ise, propolis genel olarak keskin bir ekşi tada sahiptir. Ortam şartlarının soğuk olması durumunda balmumu gibi sert, 1sı verildiğinde de yapışkan ve reçinemsi hale geçen propolis, arı yapışkanı olarak da adlandırılmaktadır [61]. Propolisin kimyasal içeriği özellikle bitki kaynağına bağlı olup; toplandığı bölgenin florası, çiçeklenme mevsimi, iklim koşulları, toplanma zamanı, tomurcuktaki reçine miktarı, polen, balmumu ve arı tarafından salgılanan madde içeriği, arı türü ve arı ırkı gibi faktörler de bileşenlerin konsantrasyonunu etkilemektedir Farklı propolis tiplerinde farklı bileşenler bulunmaktadır. Flavonoid aglikonları (flavonlar ve flavanonlar), uçucu bileşenler olarak fenolik asitler ve esterleri kavak propolisinin tipik bileşenleridir. Yeşil propolis diğer bir adıyla Brazilya propolisinin (Baccharis propolisi) tipik bileşimi ise; diterpenler ve lignanlar ile prenillenmiş p-kumarik asit ve asetofenon türevleridir [41, 61, 64-66]. Ham kavak propolisinin ve ham Brezilya propolisinin komposizyonları Tablo 6 ve Tablo 7'de gösterilmektedir.

Tablo 6. Ham kavak propolisinin bileşenleri [66-70]

\begin{tabular}{|c|c|}
\hline Bileşen & Maddeler \\
\hline \multirow{4}{*}{$\begin{array}{c}\text { Balsam } \\
(\% 40-70 \text { Ethanol ekstraktı) } \\
\underline{\text { Kavak orijinli }}\end{array}$} & Fenolikler \\
\hline & $\begin{array}{c}\text { Fenoller, fenolik asitler, esterler, flavanonlar, } \\
\text { dihidroflavononlar, flavonlar,flavonoller, kalkonlar, } \\
\text { fenolik gliseridler; }\end{array}$ \\
\hline & Diğerleri: \\
\hline & $\begin{array}{l}\text { Alifatikler: asitler, alkoller, esterler, aldehitler, } \\
\text { ketonlar, benzoik asit ve esterleri }\end{array}$ \\
\hline Esansiyel yağlar (\%1-3 ethanol ekstraktı) & Mono-, ve seskiterpenler, aromatik bileşenler \\
\hline Balsam Olmayan & Balmumu bileşenleri \\
\hline \multicolumn{2}{|l|}{$\begin{array}{c}\text { Wax (\%20-35 ethanolde çözünmeyen) } \\
\text { Balmumu orijinli }\end{array}$} \\
\hline $\begin{array}{c}\text { Diğerleri: yaklaş1k } \% 5 \text { (kısmen ethanolde } \\
\text { çözündürülmüş) } \\
\text { Arı ve polen orijinli }\end{array}$ & $\begin{array}{c}\% 2.1 \text { Mineral } \\
\% 2 \text { Polisakkaritler } \\
\% 0.7 \text { Proteinler, amino asitler, aminler ve amidler } \\
\text { Karbonhidrat, lakton, kinon, steroid ve vitemin izleri }\end{array}$ \\
\hline
\end{tabular}


Tablo 7. Ham Brezilya propolisinin bileşenleri [66, 71-74]

\begin{tabular}{|c|c|}
\hline Bileşen & Maddeler \\
\hline $\begin{array}{c}\text { Balsam } \\
(\% 45-70 \text { Ethanol ekstraktı) } \\
\text { Baccharis orijinli }\end{array}$ & $\begin{array}{l}\text { Esas olarak sinamik asit ve türevleri, } \\
\text { kumarik asit, prenillenmiş bileşikler, } \\
\text { artepillin C }\end{array}$ \\
\hline Esansiyel yağlar (\%1-3 ethanol ekstraktı) & Seskiterpenler, aromatik bileşenler \\
\hline $\begin{array}{c}\text { Balsam Olmayan } \\
\text { Wax (\%10-15 ethanolde çözünmeyen) } \\
\text { Baccharis orijinli }\end{array}$ & $\begin{array}{l}\text { Prenillenmiş bileşenler, alkanlar ve } \\
\text { terpenoidler }\end{array}$ \\
\hline $\begin{array}{c}\% 15-25 \text { ethanolde çözünmeyen } \\
\text { Balmumu orijinli }\end{array}$ & Balmumu \\
\hline $\begin{array}{c}\text { Diğerleri: yaklaşık \%5 (kısmen ethanolde } \\
\text { çözündürülmüş) } \\
\text { Arı ve polen orijinli }\end{array}$ & $\% 2.5-4.5$ Mineral \\
\hline
\end{tabular}

Kimyasal bileşimi açısından oldukça zengin olan söz konusu arı ürününün insan sağlığı üzerine olumlu etkilerinin bilinirliği çok eski yıllara dayanmaktadır. Yapılan araştırmalarda; Roma'da M.Ö. 79-23 yıllarında propolisin ağrı azaltıcı, yara iyileştirici aktivitelerine ilişkin bilgilere ulaşıldığı belirtilmektedir. Hipokrat (460-377 M.Ö.) tarafından propolisin ülser ve sindirim sistemi rahatsızlıkları ve deri hastalıkları tedavisinde uygulandığını belirtilmiştir. Afrika'da da uzun zamandır ilaç olarak kullanılan propolise dair 12. yüzyıla ait Avrupa kayıtlarında boğaz ve ağız enfeksiyonları ile diş sağlığında kullanılan tıbbi preperasyonlarının tanımları mevcuttur. Propolisin, geçmiş zamanlardan günümüze kadar insan sağlığı açısından öneminin halen bilinmesinin en önemli nedenlerinden biri de antimikrobiyal etkisidir. Bu değerli arı ürününün antiviral, antibakteriyel, antifungal özelliklerinin yanı sıra antitümör, antikanserojenik, antiülser, antiinflamatör, lokal anestezik antioksidatif, bağışıklığı koruyucu gibi yararlı biyolojik aktiviteler göstermesi; apiterapi, tıp ve biyo-kozmetik alanlarında kullanımının yaygınlaşmasını sağlamıştır [75-77].

\section{Arı Ekmeği (Perga)}

Çok bilinmeyen ve sıklıkla polen ile karıştırılan bir arı ürünü olan perga, arı ekmeği (bee bread) olarak da adlandırılmaktadır. Bu değerli arı ürününün ham maddesi polen olup; aslında arı tarafından özel olarak işlenmiş bir polendir. Oldukça zengin bir besin deposu olan arı ekmeği, yurtdışında "perga" olarak bilinmektedir. Perga; işçi arıların topladıkları polenleri nektar ve salgıladıkları enzimler ile birleştirerek özütlediği, ardından bal petekleri içerisinde paketleme yoluyla muhafaza ettikleri bir arı ürünü olarak ifade edilmektedir. Kraliçe arı ve yavru arıların en temel besini olan perga ile pupadan çıkan yavru arılar 5 gün boyunca beslenmektedir [78, 79]. Arı ekmeği piyasada nadir olarak 
bulunmaktadır. $\mathrm{Bu}$ durumun sebepleri arasında; perganın petek içine gömülü olması sebebiyle arıdan ayrıştırılmasının zorluğu, arıcıların arılarını güçlü tutma ve çoğaltma isteği, perganın kurutulamaması nedeniyle soğuk zincirde muhafaza gerektirmesi yer almaktadır [80, 81]. Perganın kimyasal bileşiminde mono- ve disakkaritler, amino asitler, çeşitli vitamin ve mineraller (kalsiyum, demir, fosfor, kobalt), enzimler ve fito-hormonlar bulunmaktadır [79]. Arı ekmeğinin kimyasal bileşimine Tablo 8'de yer verilmiştir.

Tablo 8. Arı ekmeğinin kimyasal bileşimi [82, 83]

\begin{tabular}{lc}
\hline \multicolumn{1}{c}{ Bileşen } & Bileşen miktarı $(\%)$ \\
\hline Protein & $20-22$ \\
Karbonhidrat & $24-35$ \\
Lipit & 1.6 \\
Mineral & 2.43 \\
Laktik asit & 3.5 \\
\hline
\end{tabular}

Ar1 ekmeği yapısında; insan vücudunun biyosentezleyemediği triptofan, lösin, fenilalanin, valin, arginin izolösin, metiyonin, histidin, lizin, treonin gibi esansiyel aminoasitleri; $A, B_{1}, B_{2}, B_{3}, B_{6}, B_{12}, C, P, E, D$, $\mathrm{K}, \mathrm{H}$ vitaminleri, $\mathrm{Ca}, \mathrm{Fe}, \mathrm{P}, \mathrm{S}, \mathrm{Cl}, \mathrm{K}, \mathrm{Na}, \mathrm{Mg}, \mathrm{Cu}, \mathrm{Zn}, \mathrm{Co}, \mathrm{Mo}$, Se, Cr, Si ve Ni minerelleri; sakkarozu, flavonoidleri, karatenoidleri, fosfataz ve amilaz gibi enzimleri ve çeşitli hormonları bulundurmaktadır [79, 84]. Kaplan ve ark. [85] tarafından yapılan bir çalışmada; farklı botanik ve coğrafi orijine sahip arı ekmeği örneklerinde 17 doymamış ve 20 doymuş yağ asidi olmak üzere 37 yağ asidinin tespit edildiği belirtilmiştir. Polenin etrafındaki dış kabuk nedeniyle midede sindirimi \%60 iken, perganın sindirimi arının enzimleriyle bekletilmiş ve sindirilemeyen bu kabuğun elimine edilmesi nedeniyle \%100 düzeyinde olduğu ifade edilmektedir [85]. Haydak [86] tarafindan arı ekmeği ile polen bileşiminin karşılaştırıldığ 1 bir araştırmada; aynı bitkinin poleninden daha fazla $\mathrm{K}$ vitamini ile indirgenmiş şeker, mikroorganizma sindirim enzimi içerdiği belirlenmiştir. $\mathrm{Bu}$ durumun sebebi olarak ise; polenin arı ekmeğine dönüşmesi aşamasında gerçekleşen biyokimyasal olaylar, bakteri ve mayaların laktik asit fermentasyonu gösterilmektedir. Arı ekmeği bileşiminde bulunan maddeler açısından fonksiyonel bir arı ürünü olması nedeniyle beslenme ve sağlık alanında yararlanılmaktadır. Çocuk beslenmesi başta olmak üzere; zihin yorgunluğu ve dikkat bozukluğunu azaltmada, B vitamini ve diğer vitaminler ile vücudu desteklemede, bağışıklık sistemini güçlendirmekte, vücut direncini kuvvetlendirmekte, vücut performansını artırmada, beden yorgunluğunu azaltıp enerji vererek zinde tutmakta, yaşlanmayı geciktirmede, prostat tedavisinde, bağırsak ve mide rahatsızlıklarının tedavisinde, içeriğindeki rutenyum sayesinde kalp damar tıkanıklarını önlemede, kılcal damarların duvarlarını güçlendirme gibi yararları belirlenmiştir [79, 87, 88]. 


\section{Apilarnil}

Apilarnil, ülkemizde pek bilinmemekle birlikte üretim potansiyeli yüksek olan bir arı ürünüdür. Apilarnil ismi; Api (latince arı), Lar (larva) ve Nil (Nicolae Iliesiu; ürünün etkilerini ilk keşfeden kişinin isminin ilk harfleri) birleşiminden oluşmaktadır. Apilarnil, erkek arı larvalarının petek gözü kapanmadan yani pupa döneminden önceki evre olan 3-7 günlük larval dönemi şeklinde belirtilmektedir $[89,90]$. Apilarnil; sarı-gri renkli, buruk tada sahip bir madde olup çok çabuk bozulabilmesi nedeniyle ham halde soğuk zincirde muhafaza gerektirmektedir. Arı sütü bileşimine benzer özelliklere sahip olan apilarnilin kimyasal yapısında 19 amino asit, proteinler, karbohidratlar ve lipidler, beta-karoten, mineraller, eser elementler, A, B $1, B_{2}, B_{6}$, E vitaminleri bulunmaktadır. Apilarnilin bileşimsel özellikleri Tablo 9' da verilmektedir [61, 89, 91].

Tablo 9. Apilarnilin kimyasal yapıs! [89]

\begin{tabular}{cc}
\hline Bileşen & Bileşen miktarı (\%) \\
\hline Nem & $\% 65-75$ \\
Kuru Madde & $\% 25-35$ \\
Toplam protein & $6-10 \mathrm{~g}$ \\
Toplam karbonhidrat & $\% 11-13$ \\
Toplam Yağ & $5-8 \mathrm{~g}$ \\
Fosfor & $\% 0.5$ \\
Kül (en çok) & $\% 2$ \\
Bilinmeyen Maddeler (en çok) & $\% 3$ \\
\hline
\end{tabular}

Apilarnil bileşiminde bulunan mineraller arasında demir, kalsiyum, fosfor, sodyum, potasyum, çinko, manganez ve bakır yer almaktadır. Protein açısından kırmızı etten sonra ikinci sırada yer alan apilarnil, D vitamini miktarı açısından ise balık yağından 10 kat daha yüksek değere sahiptir [81]. Arı sütü kadar yararlı olan apilarnil; erkek ve kadınlarda üreme fonksiyonlarını iyileştirmede, hayvan beslenmesi, vücut kas ağırlı̆̆ı artırma, anokresiyada, prematüre çocukların gelişmesi, hafızanın geliştirilmesi, ilköğretim çağındaki çocukların zihinsel performanslarının arttırılması, vücut enerjisini, canlılığını ve yenileme gücünü artırma, endokrin hipofiz ve adrenal bezlerin yetersizliği, geriatri, bağışıklık sistemi hastalıklarının tedavileri amacıyla kullanılabilmektedir [61].

\section{Arı Zehiri}

Arıların savunma mekanizması olan arı zehiri; berrak, keskin acımsı tada sahip, ekşimsi kokulu, hava ile temasında çabuk kuruyan sıvı bir arı ürünüdür [92]. Zehir kesesinde depolanan arı zehiri, arının iğnesi aracılığıyla pompalanarak dışarıya verilir. Zehir miktarı arının yaşına göre değişmekte olup; 16-19 günlük arılarda en yüksek seviyede olduğu ifade edilmektedir [41]. Yapılan araştırmalarda arıların zehir miktarının yaklaşık 0.05-0.3 ml/arı arasında olduğu belirtilmiştir [93]. Günümüzde zehir toplama işlemi cam levha yüzeyinde ince elektrik telleri gerilmiş bir aletten yararlanılan elektroşok yöntemi ile gerçekleşmektedir. Arılar elektrik tellerine bastığı esnada elektrik verilerek hafifçe uyarıldığında, cam 
plakayı sokmaya çalışmakta ve böylece zehrini bırakmaktadırlar. Cam plakada hızla kuruyan zehir, jilet veya bıçak ile kazınarak çıkartılmaktadır. Arı zehirini kuru halde yalnızca 1 gram elde edebilmek için en az bir milyon iğne gerekmektedir [94]. Arıların zehir kesesinde oluşturdukları bu arı ürününün kimyasal yapısı oldukça komplekstir. Kuru arı zehrinin kimyasal yapısı Tablo 10'da verilmektedir.

Tablo 10. Kuru arı zehrinin bileșimi [95].

\begin{tabular}{|c|c|c|}
\hline Madde Grubu & Bileşen & $\begin{array}{l}\text { Kuru Maddede } \\
(\%)\end{array}$ \\
\hline \multirow{5}{*}{ Proteinler } & Fosfolipaz A2 & $10-12$ \\
\hline & Fosfolipaz B & 1 \\
\hline & Hyaluronidaz & $1-2$ \\
\hline & Fosfotaz & 1 \\
\hline & $\alpha$-Glukozidaz & 0.6 \\
\hline \multirow{10}{*}{ Peptitler } & Melittin & $40-50$ \\
\hline & Apamin & $2-3$ \\
\hline & MCD Peptit & $2-3$ \\
\hline & Sekapin & $0.5-2$ \\
\hline & Pamin & $1-3$ \\
\hline & Minimin & 2 \\
\hline & Adolapin & $0.5-1$ \\
\hline & Prokamin A, B & $1-2$ \\
\hline & Proteaz İnhibitör & $0.1-0.8$ \\
\hline & Tertiapin,kardiopep, melittin F & $1-2$ \\
\hline Fosfolipitler & & $1-3$ \\
\hline \multirow{3}{*}{ Biyolojik Aminler } & Histamin & $0.5-2$ \\
\hline & Dopamin & $0.2-1$ \\
\hline & Noradrenalin & $0.1-0.5$ \\
\hline Amino asitler & Aminobütirik asit, $\alpha$-amino asitler & 1 \\
\hline Şekerler & Glukoz, Fruktoz & $2-4$ \\
\hline Uçucu bileşenler (feromonlar) & Kompleks etherler & $4-8$ \\
\hline Mineraller & $\mathrm{P}, \mathrm{Ca}, \mathrm{Mg}$ & $3-4$ \\
\hline
\end{tabular}

Arı zehri bileşiminde bulunan melittin, histamin, hyalüronidaz, apamin, amino asitler, proteinler, MCD (mast cell degranulation) peptidi, fosfolipaz-A gibi maddeler biyokimyasal ve farmakolojik açıdan önem taşımaktadır [41]. Uzun yıllardır geleneksel tıpta kullanılan arı zehiri, araştırmacıların bileşiminde bulunan söz konusu maddelerin belirlenmesiyle tamamlayıcı tıp alanında da yerini almıştır. Arı zehirinin uygulanma şekli; ilaç ve krem formülasyonları, arı zehiri tozu, doğrudan zehir uygulaması ve direkt arı sokmasıdır. Arı zehiri bel ağrısı, migren, romatizma, multiple skleroz (MS), mafsal iltihabı (arterit), kronik yorgunluk sendromu, doku sertleşmesi, gut hastalığı, yara izleri, ekzema, alerjik hastalıklar, epilepsi, astım, boğaz enfeksiyonlarının tedavisi amacıyla uygulanmaktadır [41, 95]. 


\section{Balmumu}

Balmumu 13-18 günlük işçi arıların karın halkalarının alt yüzünde yer alan balmumu salgı bezleri tarafindan salgılanan, ham maddesi bal olan bir arı ürünüdür. Saf balmumu salgılandığında, ince saydam beyaz renkli görünüştedir ancak; sonraki etapta polenden geçen ve yağda çözünebilen karotenoid pigmentlerinden dolayı sarı renge dönüşmekte ve katılaşmaktadır. Arılar kilogram balmumu başına 8$21 \mathrm{~kg}$ arasında bal tüketmektedirler. Bal mumunun özgül ağırlı̆̆ $0,95 \mathrm{~g} / \mathrm{cm}^{3}$ olup, $64,5^{\circ} \mathrm{C}^{\prime}$ de erimeye başlamakta, $85^{\circ} \mathrm{C}$ 'de de tamamen erimektedir. Söz konusu arı ürünü eter, benzen ve kloroformda tamamen, soğuk alkolde az çözünmekte iken suda çözünmemektedir [41, 94]. Balmumunun kimyasal özelliklerine ise Tablo 11'de gösterilmektedir.

\begin{tabular}{cc} 
Tablo 11. Balmumunun kimyasal yapısı [26, 96, 97] \\
\hline Bileşen & Bileşen miktarı (\%) \\
\hline Hidrokarbonlar & 14 \\
Monoesterler & 35 \\
Diesterler & 14 \\
Triesterler & 3 \\
Hidroksi mono- ve & 12 \\
poliesterler & \\
Asit esterler & 1 \\
Poliesterler & 2 \\
Serbest asitler & 12 \\
Serbest alkoller & 1 \\
Diğer maddeler & 6 \\
\hline
\end{tabular}

Tablo 11'de de görüldüğü üzere; balmumunda değişik oranlarda, uzun zincirli hidrokarbonlar ve uzun zincirli yağ asitleri, mono-, di- ve triesterler, hidroksi- ve poliesterler, asit ve poliesterler bulunmaktadır. Mum, bal arıları tarafından balın olgunlaştırılması amacıyla olgunlaşmış balın üst yüzeyinin kaplanması için kullanılmaktadır. Bal mumu ile bir miktar propolis birlikte yavruları enfeksiyonlardan ve kurumadan korumanın yanı sıra yabancı nesneleri kaplama, kovandaki çatlakları kapatma amacıyla kullanılmaktadır. Balmumunun kullanım alanlarının başında petek yapımı gelmektedir. Balmumu diğer arı ürünlerine kıyasla kullanım alanı oldukça geniş olan bir maddedir. Zamksı yapısından dolayı Mısır mumyalarının sargılarında kullanılan bal mumu; ilaç sanayiinde, diş tedavisinde, mide koruyucu, ishal önleyici, küçük ölçekli yanık ve diğer deri tahribatlarında ve hava yolu ile gelen alerjik etkilere karşı derinin korunması amacıyla kullanılmaktadır. Balmumundan; temel petek yapımı ve sağlık amacıyla kullanımının yanı sıra; kozmetik sanayii, mum, sakız su geçirmez malzeme, mobilya ve zemin cilalarının üretimi, optik lenslerin parlatılması gibi pek çok alanda yararlanılmaktadır [41, 61, 98].

\section{Sonuç}

Doğanın bir mucizesi olarak nitelendirdiğimiz balın yanı sıra; arı ürünlerinin her biri de gerek besleyici özellik gerekse fonksiyonellik açıdan birer mucize olarak görülmektedir. Tüm arı ürünlerinin önemi her 
ne kadar bilinse de bal her zaman tüketimi en fazla olan arı ürünü olmuştur. Ancak günümüzde yapılan çalışmalar ile propolis, arı sütü, polen, arı ekmeği, apilarnil, arı zehiri ve balmumunun önemleri daha da gün yüzüne çıkmış olup; gelişen teknoloji ile söz konusu ürünlerin bileşenlerinin tespiti ve fonksiyonel özellikleri üzerine araştırmalar yoğunlaştırılmıştır. Söz konusu araştırmalar ile arı ürünlerinin özellikle beslenme ve insan sağlığı üzerine olumlu etkileri tespit edilmiştir. Apiterapi olarak adlandırılan arı ürünlerinin, bir ya da birden fazla hastalığın önlenmesi ya da iyileştirilmesi amacıyla kullanılması geçmişte olduğu gibi bugün de tamamlayıcı tıp alanında önemli bir yerdedir. Ancak bu ürünlerin kullanımı için alerjen etkileri ve doz miktarlarının hassasiyetle belirlenmesi gerekmekte olup; toksikolojik çalışmaların yoğunlaştırılmasının insan sağlığı açısından faydalı olacağı düşünülmektedir. $\mathrm{Bu}$ sayede; ileriki yıllarda arı ürünlerinin gıda, tıp, farmakoloji, kozmetik gibi pek çok alanda bilinirliğinin ve bilinçli kullanım düzeyinin artış göstereceği öngörülmektedir.

\section{Teşekkür -}

Fon/Finansman Bilgileri Herhangi bir kurum ve/veya kuruluş tarafından desteklenmemiştir.

Etik Kurul Onayı ve İzinler Çalışma, etik kurul izni ve herhangi bir özel izin gerektirmemektedir.

Çıkar Çatışmaları/Çatışan Çıkarlar Yazarlar çıkar çatışması olmadığını beyan eder.

Yazarların Katkısı Tüm yazarlar, çalışmaya eşit oranda katkı sağlamıştır. Tüm yazarlar makalenin son halini okumuş ve onaylamıştır.

\section{Kaynaklar}

[1] Sarı̈̈, P. (2006). Deli bal. Arı Biziz Bal Bizdedir: Dünden Bugüne Türkiye'de Arıcılı. Balparmak Yayınları, İstanbul, 114-115.

[2] Yaşar, N. (2010). Arı ve insan. Arıcılık Araştırma Dergisi, 2 (3): 9-10.

[3] Güler, A. (2006). Bal arısı (Apis mellifera L.) Yetiştiriciliği Hastalıkları ve Ürünleri. Ondokuz Mayıs Üniversitesi Ziraat Fakültesi Ders Kitabı No: 55, Samsun, 574s.

[4] Ruttner, F. (1988). Biogeography and Taxonomy of Honeybees. Springer-Verlag, Berlin Heidelberg, $284 \mathrm{~s}$.

[5] Smith, D. R. (2002). Genetic diversity in Turkish Honey Bees. Uludă̆ Arıcılık Dergisi, 2(3), 10-17.

[6] TUIK. (2021, 15 Aralık). Türkiye İstatistik Kurumu: Hayvansal Üretim İstatistikleri: Arıcılık, Istatistik Veri Portall. https://data.tuik.gov.tr/Search/Search?text=arıcılık

[7] TGK. (2020). Türk Gıda Kodeksi: Bal Tebliği. Resmi Gazete, 22 Nisan 2020- 31107. Tebliğ No: 2020/7. https://www.resmigazete.gov.tr/eskiler/2020/04/20200422-13.htm

[8] Sunay, A. E., \& Samanc1, T. (2008). Arı Ürünleri Üretimi. BAL-DER Arı Ürünleri ile Sağlıklı Yaşam Platformu Derneği. http://www.balder.org.tr/sunumlar/Asli_Sunay_sempozyum_(No_17).pdf.

[9] Karabagias, I. K., Badeka, A.V., Kontakos, S., Karabournioti, S., \& Kontominas, M. G. (2014). Botanical discrimination of Greek unifloral honeys with physico-chemical and chemometric analyses. Food Chemistry, 165, 181-190. https://doi.org/10.1016/j.foodchem.2014.05.033 
[10] Özmen, N., \& Alkın, E. (2006). Balın antimikrobiyel özellikleri ve insan sağlığı üzerine etkileri. Uludă̆ Arıcılık Dergisi, 4, 155-160.

[11] Spilioti, E., Jaakkola, M., Tolonen, T., Lipponen, M., Virtanen, V., Chinou, I., Kassi, E., Karabournioti, S., \& Moutsatsou, P. (2014). Phenolic acid composition, antiatherogenic and anticancer potential of honeys derived from various regions in Greece. Plos One, 9(4), 1-10. https://doi.org/10.1371/journal.pone.0094860

[12] Bogdanov, S. (1997). Nature and origin of the antibacterial substances in honey. LWT - Food Science and Technology, 30(7), 748-753. https://doi.org/10.1006/fstl.1997.0259

[13] Bogdanov, S., Jurendic, T., Sieber, R., \& Gallmann, P. (2008). Honey for nutrition and health: A review. Journal of the American College of Nutrition, 27(6), 677-689. http://doi.org/10.1080/07315724.2008.10719745

[14] Saber, A. (2010). Ancient Egyptian surgical heritage. Journal of Investigative Surgery, 23(6), 327334. http://doi.org/10.3109/08941939.2010.515289

[15] Martos, I., Cossentini, M., Ferreres, F., \& Tomas-Barberan, F. A. (1997). Flavanoid composition of Tunisian honey and propolis. Journal of Agricultural and Food Chemistry, 45(8), 2824-2829. https://doi.org/10.1021/jf9609284

[16] Bayrak, N. (2005). Arı ürünlerinin (bal, arıütü, polen ve propolis) mikrofloralarının ve antimikrobiyal aktivitelerinin incelenmesi. (Tez No. 169266) [Yüksek Lisans Tezi, Frat Üniversitesi].

[17] Weston, R. J., Brocklebank, L. K., \& Lu, Y. (2000). Identification and quantitative levels of antibacterial components of some New Zealand honeys. Food Chemistry, 70(4), 427-435. http://doi.org/10.1016/S0308-8146(00)00127-8

[18] Malika, N., Mohamed, F., Chakib, E. A. (2004). Antimicrobial activities of natural honey from aromatic and medicinal plants on antibio-resistant strains of bacteria. International Journal of Agriculture \& Biology, 6(2), 289-293.

[19] Alvarez-Suarez, J. M., Tulipani, S., Diaz D., Estevez, Y., Romadini, S., Giampieri, F., Damiani, E., Astolfi, P., Bompadre, S., \& Battino, M. (2010). Antioxidant and antimicrobial capacity of several monofloral Cuban honeys and their correlation with color, polyphenol content and other chemical compounds. Food and Chemical Toxicology. 48(8-9), 2499. http://doi.org/10.1016/j.fct.2010.06.021

[20] Stephens, J. M., Schlothauer, R. C., Morris, B. D., Yang, D., Fearnley, L., Greenwood, D. R., \& Loomes, K. M. (2010). Phenolic compounds and methylglyoxal in some New Zealand manuka and kanuka honeys. Food Chemistry, 120(1), 78-86. http://doi.org/10.1016/j.foodchem.2009.09.074

[21] Brudzynski, K., \& Kim, L. (2011). Storage-induced chemical changes in active components of honey de-regulate its antibacterial activity. Food Chemistry, 126(3), 1155-1163. http://doi.org/10.1016/j.foodchem.2010.11.151

[22] Silici, S. (2019). Honeybee products and apitherapy. Turkish Journal of Agriculture - Food Science and Technology, 7(9), 1249-1262. https://doi.org/10.24925/turjaf.v7i9.1249-1262.2141

[23] Al Somali, N., Coley, K. E., Molan, P. C., \& Hancock, B. M. (1994). Susceptibility of Helicobacter pylori to the antibacterial activity of manuka honey. Journal of the Royal Society of Medicine, 87(1), 912. https://www.ncbi.nlm.nih.gov/pmc/articles/PMC1294271 
[24] Molan, P. C. (1997). Honey as an antimicrobial agent. In A. Mizrahi, Y. Lensky, (Eds), Bee Products: Properties, Applications, and Apitherapy, Springer, Boston MA, 27-37.

[25] Postmes, Th. J., Bosch, M. M. C., Dutrieux, R., van Baare, J., \& Hoekstra, M. J. (1997). Speeding up the healing of burns with honey. In A. Mizrahi, Y. Lensky, (Eds), Bee Products: Properties, Applications, and Apitherapy, Springer, Boston MA, 57-63.

[26] Schmidt, J. O. (1997). Bee Products. In A. Mizrahi, Y. Lensky, (Eds), Bee Products: Properties, Applications, and Apitherapy, Springer, Boston MA, 15-26.

[27] Molan, P. C. (2000). Balın modern tıpta kullanımı. Çeviren: M. Civan. Teknik Arıcılık, 67, 25-31.

[28] Nemoseck, T., Cholish, D., Petrisko, Y., \& Kern, M. (2010). Effects of consumption of honey, sucrose and glucose on satiety and postprandial metabolism in healthy subjects. The FASEB Journal, 24, 553-4. https://doi.org/10.1096/fasebj.24.1_supplement.553.4

[29] Abdulrhman, M., El-Hefnawy, M., Hussein, R., \& Abou El-Goud, A. (2011). The glycemic and peak incremental indices of honey, sucrose and glucose in patients with type 1 diabetes mellitus: effects on C-peptide level - a pilot study. Acta Diabetologica, 48(2), 89-94. http://doi.org/10.1007/s00592-0090167-7

[30] El Denshary, E. S., Al-Gahazali, M. A., Mannaa, F. A., Salem, H. A., Hassan, N. S., \& AbdelWahhab, M. A. (2011). Dietary honey and ginseng protect against carbon tetrachloride-induced hepatonephrotoxicity in rats. Experimental and Toxicologic Pathology, 64(7-8), 753-760. http://doi.org/10.1016/j.etp.2011.01.012

[31] Badet, C., \& Quero, F. (2011). The in vitro effect of manuka honeys on growth and adherence of oral bacteria. Anaerobe, 17(1), 19-22. http://doi.org/10.1016/j.anaerobe.2010.12.007

[32] Samarghandian, S., Afshari, J. T., \& Davoodi, S. (2011a). Chrysin reduces proliferation and induces apoptosis in the human prostate cancer cell line pc-3. Clinics, 66(6), 1073-1079. http://doi.org/10.1590/s1807-59322011000600026

[33] Samarghandian, S., Afshari, J. T., \& Davoodi S. (2011b). Honey induces apoptosis in renal cell carcinoma. Pharmacognosy Magazine, 7(25), 46-52. http://doi.org/10.4103/0973-1296.75901

[34] Fauzi, A. N., Norazmi, M. N., \& Yaacob, N. S. (2011). Tualang honey induces apoptosis and disrupts the mitochondrial membrane potential of human breast and cervical cancer cell lines. Food and Chemical Toxicology, 49(4), 871-878. http://doi.org/10.1016/j.fct.2010.12.010

[35] Othman, N. H. (2012). Honey and cancer: Sustainable inverse relationship particularly for developing nations-a review. Evidence-Based Complementary and Alternative Medicine. 2012, A 410406, 10p. http://doi.org/10.1155/2012/410406

[36] Saha, A., \& Mandal, S. (2015). In vitro assessment of two commercial honey samples for antibacterial and antioxidant activities. Austin Journal of Tropical Medicine \& Hygiene, 1(1), 1002.

[37] Pasupuleti, V. R., Sammugam, L., Ramesh, N., \& Gan, S. H. (2017). Honey, propolis, and royal jelly: A comprehensive review of their biological actions and health benefits. Oxidative Medicine and Cellular Longevity, 2017, 1259510, 21s. https://doi.org/10.1155/2017/1259510

[38] Sorkun, K., Özkök, A., \& Süer, B. (2001). Arılar tarafından toplanan polenin işlenmesi ve kullanım alanları. Teknik Arıcılık, 74, 9-15.

[39] Süer, B., \& Sorkun, K. (2006). Arılar tarafından toplanan polenin kimyasal, fiziksel özellikleri ve kovandan toplanmas1. Teknik Arıcllı, 73, 16-21. 
[40] Çankaya, N., \& Korkmaz, A. (2008). Polen. Samsun Valiliği İl Tarım Müdürlüğü Çiftçi Eğitimi ve Yayım Şubesi Yayını, Samsun, 19s.

[41] Tutkun, E. (2011). Arıcılık Tekniği. Genişletilmiş 2. Bask1. Önder Matbaacılık Ltd.Şti., 364s.

[42] Szczêsna, T. (2006). Protein content and amino acid composition of bee-collected pollen from selected botanical origins. Journal of Apicultural Science, 50(2), 81-90.

[43] Campos, M. G. R., Bogdanov, S., de Almeida Muradian, L. B., Szczesna, T., Mancebo, Y., Frigerio, C., \& Ferreira, F. (2008). Pollen composition and standardisation of analytical methods. Journal of Apicultural Research, 47(2), 154-161. https://doi.org/10.1080/00218839.2008.11101443

[44] Bogdanov, S. (2016a). Pollen: collection, harvest, composition, quality. The Bee Pollen Book, Chapter 1, 13s.

[45] Bogdanov, S. (2016b). Pollen: nutrition, functional properties, health. The Bee Pollen Book, Chapter 2, 30s.

[46] Öztürk, A. İ. \& Akçiçek, E. 2015. Polen ve Polenin Tıbbi Özellikleri. In F. Akçiçek, E. ve Yücel, B. (Eds) Arı Ürünleri ve Sağllk (Apiterapi), Sidas Yayıncılık. 256s.

[47] Bleha, R., Shevtsova, T., Kružík, V., Brindza, J., \& Sinica, A. (2019). Morphology, physicochemical properties and antioxidant capacity of bee pollens. Czech Journal of Food Sciences, 37(1), 1-8. https://doi.org/10.17221/139/2018-CJFS

[48] Ulusoy, E. (2010). Anzer balı ve poleninin yüksek performanslı slvı kromatografisi ile fenolik bileşiminin belirlenmesi ve antioksidan özellikleri. (Tez No. 276134) [Doktora Tezi, Karadeniz Teknik Üniversitesi].

[49] Doğaroğlu, M., \& Doğaroğlu O. K. (2012). Modern Arıcılık Teknikleri. 4.Bask1, Tekirdağ, 304s.

[50] Korkmaz, A., \& Akyol, E. (2015). Arı Sütü Üretimi. 1. Bask1, Ceylan Ofset Matbaac1lık, Samsun, $58 \mathrm{~s}$.

[51] Arslan, A., \& Bayraktar, A. (1988). Arı sütü ve kimyasal bileşimi. Teknik Arıcılık Dergisi, 8, 27 30. (Alınmıştır: Akyol, E., \& Baran, Y. (2015). Arı sütünün yapısı, insanlar ve arılar için önemi. Uludăg Arıcılık Dergisi, 15(1), 16-21. https://doi.org/10.31467/uluaricilik.377563)

[52] Sabatini A. G., Marcazzan, G., Caboni, M. F., Bogdanov, S., \& de Almeida-Muradian, L. B. (2009). Quality and standardisation of royal jelly. Journal of ApiProduct and ApiMedical Science, 1(1), 16-21. http://doi.org/10.3896/IBRA.4.01.1.04

[53] Bogdanov, S. (2016c). Royal jelly and bee brood: Harvest, composition, quality. The Royal Jelly Book, Chapter 1, 14s.

[54] Akyol, E. (2015). Arı sütünün yapısı, insanlar ve arılar için önemi. Uludağ Arıcılık Dergisi, 15(1), 1-16. https://doi.org/10.31467/uluaricilik.377563

[55] Bogdanov, S. (2016d). Royal jelly, bee brood: Composition, nutrition, health. The Royal Jelly Book, Chapter 2, 35s.

[56] TSE. (2000). Türk Standartları Enstitüsü: Arı Sütü Standardı, TS 6666, Ankara.

[57] Yatsunami, K., \& Echigo, T. (1985). Antibacterial action of royal jelly. Bulletin of the Faculty of Agriculture, The Tamagawa University, 25, 13-22. (Alınmıştır: Ramadan, M. F., \& Al-Ghamdi A. (2012). Bioactive compounds and health-promoting propertiesof royal jelly: A review. Journal of Functional Foods, 4(1), 39-52. https://doi.org/10.1016/j.jff.2011.12.007 
[58] Ramadan, M. F., \& Al-Ghamdi A. (2012). Bioactive compounds and health-promoting properties of royal jelly: A review. Journal of Functional Foods, 4(1), 39-52. https://doi.org/10.1016/j.jff.2011.12.007

[59] Nagai, T., \& Inoue, R. (2004). Preparation and functional properties of water extract and alkaline extract from royal jelly. Food Chemistry, 84(2), 181-186. http://doi.org/10.1016/S0308-8146(03)001985

[60] Meydanoğlu, F. (1988). Arı sütünün bilesimi, diyetetik terapötik özellikleri. Diabet Yıllığı. İstanbul Üniversitesi Fen Fakültesi Prof. Dr. Nazım Terzioğlu Basın Atölyesi, İstanbul.

[61] Mert, G. (2007, 17-18 Mayıs). Apiterapi, Arı Ürünleri ve Tıpta Kullanımı [Konferans sunumu] 3. Ulusal Zootekni Öğrenci Kongresi, Sütçü İmam Üniversitesi, Kahramanmaraş.

[62] Çakıcı, N., Atmaca, H., \& Ustaoğlu, E. (2019). Apiterapi. Olay Gazetecilik Matbaacılık ve Tic. Ltd. Şti., Ordu.

[63] Çelik, K., \& Aşgun, H. F. (2016). Arllarla Gelen Sağllk “Apiterapi”, 104s. http://apitherapyproject.eu/pdf/20160920/apitherapy-handbook-tr.pdf

[64] Kutluca, S., Genç, F., \& Korkmaz, A. (2008). Propolis. Samsun Valiliği İl Tarım Müdürlüğü Çiftçi Eğitimi ve Yayım Şubesi Yayını, Samsun, https://samsun.tarimorman.gov.tr/Belgeler/Yayinlar/Kitaplarimiz/propolis.pdf

[65] Oruç, H. H., Sorucu, A., \& Aydın, L. (2014). Propolisin sağlık açısından önemi, kalitesinin belirlenmesi ve Türkiye açısından irdelenmesi. Uludă̆ Arıcılık Dergisi, 14(1), 35-43.

[66] Bogdanov, S., \& Bankova, V. (2016). Propolis: Origine, production, composition. The Propolis Book, Chapter 1, 21s.

[67] Bankova, V., Popova, M., \& Trusheva, B. (2014). Propolis volatile compounds: chemical diversity and biological activity: A Review. Chemistry Central Journal, 8(28), 1-8. http://doi.org/10.1186/1752$153 \mathrm{X}-8-28$

[68] Cvek, J., Medii-Saric, M., Vitali, D., Mornar, A., Vedrina-Dragojevic, I., Smit, Z., \& Tomic, S. (2008). The content of essential and toxic elements in Croatian propolis samples and their tinctures. Journal of Apicultureal Research and Bee World, 47(1), 35-45. https://doi.org/10.1080/00218839.2008.11101421

[69] Popova, M., Bankova, V., Butovska, D., Petkov, V., Nikolova-Damyanova, B., Sabatini, A. G., Marcazzan, G. L., \& Bogdanov, S. (2004). Validated methods for the quantification of biologically active constituents of poplar-type propolis. Phytochemical Analysis, 15(4), 235-240. http://doi.org/10.1002/pca.777

[70] Qian, W. L., Khan, Z., Watson, D. G., \& Fearnley, J. (2008). Analysis of sugars in bee pollen and propolis by ligand exchange chromatography in combination with pulsed amperometric detection and mass spectrometry. Journal of Food Composition and Analysis, 21(1), 78-83. https://doi.org/10.1016/j.jfca.2007.07.001

[71] Chang, R., Pilo-Veloso, D.; Morais, S. A. L, \& Nascimento, E. A. (2008). Analysis of a Brazilian green propolis from Baccharis dracunculifolia by HPLC-APCI-MS and GC-MS. Brazilian Journal of Pharmacognosy, 18(4), 549-556. http://doi.org/10.1590/S0102-695X2008000400009

[72] Cunha, I. B. S, Sawaya, A. C. H. F., Caetano, F. M., Shimizu, M. T., Marcucci, M. C., Drezza, F. T., Povia, G. S., \& Carvalho, P. O. (2004). Factors that influence the yield and composition of Brazilian 
propolis extracts. Journal of the Brazilian Chemical Society, 15(6), 964-970. https://doi.org/10.1590/S0103-50532004000600026

[73] Pereira, A. S., Bicalho, B., \& Aquino Neto, F. R. (2003). Comparison of propolis from Apis mellifera and Tetragonisca angustula. Apidologie, 34(3), 291-298. https://doi.org/10.1051/apido:2003023

[74] Pereira, A. S, Norsell, M., Cardoso, J. N., Aquino Neto, F. R., \& Ramos, M. F. S. (2000). Rapid screening of polar compounds in Brazilian propolis by high-temperature high-resolution gas chromatography-mass spectrometry. Journal of Agricultural and Food Chemistry, 48(11), 5226-5230. http://doi.org/10.1021/jf000594p

[75] Graikou, K., Popova, M., Gortzi, O., Bankova, V., \& Chinou, I. (2016). Characterization and biological evaluation of selected Mediterranean propolis Samples. Is it a new type? LWT - Food Science and Technology, 65, 261-267. http://dx.doi.org/10.1016/j.lwt.2015.08.025

[76] Yıldırım, A., Duran, G. G., Duran, N., Jenedi, K., Bolgül, B. S., Miraloğlu, M., \& Muz, M. (2016). Antiviral activity of Hatay propolis against replication of herpes simplex virus type 1 and type 2 . Medical Science Monitor, 22, 422-430. http://doi.org/10.12659/MSM.897282

[77] Dezmirean, D. S., Marghitaş, L. A., Chirila, F., Copaciu, F., Simonca, V., Bobiş, O., \& Erler, S. (2017). Influence of geographic origin, plant source and polyphenolic substances on antimicrobial properties of propolis against human and honey bee pathogens. Journal of Apicultural Research, 56(5), 588-597. https://doi.org/10.1080/00218839.2017.1356205

[78] Karaman, M. R., Artık, N., \& Küçükersan, K. (2016, 26-30 Ekim). Perga (Bee Bread) Composition and Health Benefit. [Konferans sunumu]. The 2nd International Turkic World Conference on Chemical Sciences and Technologies, Skopje, Macedonia.

[79] Karaman, M. R., Artık, N., Küçükersan, K., Halıcı, Z., \& Çelik, M. (2017). Sağlıklı beslenme ve apiterapi için değerli bir arı ürünü: Perga (bee bread). Gıda 2000 Glda Teknoloji ve Tarım Dergisi, 8s. https://www.gida2000.com/saglikli-beslenme-ve-apiterapi-icin-degerli-bir-ari-urunu-perga-bee-bread2.html

[80] Silici, S. (2015). Arı poleni ve arı ekmeği. Uludă̆ Arıcılık Dergisi, 14(2), 99-105. https://doi.org/10.31467/uluaricilik.376901

[81] Özkök, A. (2016). Arı ürünleri arı ekmeği ve apilarnil. Eğlenceli Bilim, Atılım Üniversitesi Popüler Bilim Dergisi, 19, 3-6.

[82] Čeksterytė, V., Račys, J., Kaškonienė, V., \& Venskutonis, P. R. (2008). Fatty acid composition in beebread. Biologija, 54,(4), 253-257. http://doi.org/10.2478/v10054-008-0052-2

[83] Vásquez, A., \& Olofsson, T. C. (2009). The lactic acid bacteria involved in the production of bee pollen and bee bread. Journal of Apicultural Research, 48(3), 189-95. https://doi.org/10.3896/IBRA.1.48.3.07

[84] Haydak, M. H., \& Vivino, A. E. (1950). The changes in thiamine, riboflavin, niacin and pantothenic acid content in the food of female honeybees during growth with a note on the vitamin $\mathrm{K}$ activity of royal jelly and bee bread. Annnals of the Entomological Society of America, 43, 361-367. (Alınmıştır: Silici, S. (2015). Arı poleni ve arı ekmeği. Uludă̆ Arıcılık Dergisi, 14(2), 99-105. https://doi.org/10.31467/uluaricilik.376901 
[85] Kaplan, M., Karaoğlu, Ö., \& Silici, S. (2015, 23-28 Ağustos). Farklı Botanik ve Coğrafi Orijinlere Sahip Arı Ekmeği Örneklerinin Kimyasal ve Palinolojik Analizi. [Konferans sunumu]. 27. Ulusal Kimya Kongresi, Çanakkale.

[86] Haydak, M. H. (1958). Pollen substitutes. Proceedings of the Tenth International Congress of Entomology, Montreal, 4, 1053-1056. (Alınmıştır: Silici, S. (2015). Arı poleni ve arı ekmeği. Uludăg Arlcılık Dergisi, 14(2), 99-105. https://doi.org/10.31467/uluaricilik.376901

[87] Pascoal, A., Rodrigues, S., Teixeira, A., Feás X., \& Estevinho, L. M. (2014). Biological activities of commercial bee pollens: Antimicrobial, antimutagenic, antioxidant and anti-inflammatory. Food and Chemical Toxicology, 63, 233-239. http://doi.org/10.1016/j.fct.2013.11.010

[88] Abouda, Z., Zerdani, I., Kalalou, I., Faid, M., \& Ahami, M. T. (2011). The Antibacterial activity of Moroccan bee bread and bee-pollen (fresh and dried) against pathogenic bacteria. Research Journal of Microbiology, 6(4), 376-384. http://doi.org/10.3923/jm.2011.376.384

[89] Yücel, B., \& Kösoğlu, M. (2015). Apiterapi'de Apilarnil. In F. Akçiçek, E. ve Yücel, B. (Eds) Art Ürünleri ve Sağllk (Apiterapi), Sidas Yayıncılık. 256s.

[90] Şahin, P., Arıül Apan, M., \& Mehmetoğlu, M. (2019). Arı Ürünleri. Olay Gazetecilik ve Matbaacılık ve Tic. Ltd. Şti., Ordu.

[91] Bărnuţiu, L. I., Mărghitaş, L. Al., Dezmirean, D., Bobiş, O., Mihai, C., \& Pavel, C. (2013). Physicochemical composition of apilarnil (bee drone larvae). Lucrări Ştiinţifice-Seria Zootehnie, 59, 199-202.

[92] TSE. (1989). Türk Standartları Enstitüsü Standard Tasarısı: Ari Zehiri Toplayacısı, Ankara.

[93] Habermann, E. (1972). Bee and wasp wenome. Science, 177(117), 314-322.

[94] Korkmaz, A. (2013). Anlaşılabilir Arıcılık. Samsun Gıda Tarım ve Hayvancılık İl Müdürlüğü Yayın1, Samsun. 331s.

[95] Bogdanov, S. (2016e). Bee venom: Production, composition, quality. The Bee Venom Book, Chapter 1, 9s.

[96] Şahinler, N. (2000). Arı ürünleri ve insan sağlığı açısından önemi. MKÜ Ziraat Fakültesi Dergisi, 5(1-2), 139-148.

[97] Callow, R. K. (1963). Chemical and Biochemical problems of beeswax. Bee World, 44(3), 95-101. https://doi.org/10.1080/0005772X.1963.11096997

[98] Bogdanov, S. (2016f). Beeswax: History, uses, trade. Online Beeswax Book, Chapter 2, 18s. 